\title{
NEW PERIODICALS
}

\section{Canadian Bulletin of Medical History}

This publication of the Canadian Society for the History of Medicine is a continuation of its Nouvelles/Newsletter, issued 1978-83. Two issues will be published each year, in June and November. Manuscripts are invited, in the French or in the English language, on all aspects of the care of the sick or the people's health. Illustrations will be included. These may be formal papers, which will be sent for review, or shorter articles, which will be informally editorialized. Manuscripts for consideration should be sent to Dr.K.B Roberts, Faculty of Medicine, Memorial University, St John's, Newfoundland A1B 3V6.

The cost of membership (corporate or individual) of the Canadian Society for the History of Medicine is $\$ \mathrm{Cdn} 15.00$; this subscription includes the Bulletin.

\section{Uppsala Newsletter (History of Science)}

Uppsala Newsletter is an occasional publication of at least two issues a year. It is published by the Office for History of Science at Uppsala University as an attempt to give surveys and information about this discipline in Scandinavia. The Newsletter will include the history of medicine and technology, and will be sent free of charge to anyone interested. Please write to the Editor (Tore Frängsmyr), Office for History of Science, Uppsala University, Box 256, S-75105 Uppsala, Sweden.

\section{BOOKS ALSO RECEIVED}

(The inclusion of a title in this list does not preclude the possibility of subsequent review. Items received, other than those assigned for review, are ultimately incorporated into the collection of the Wellcome Institute for the History of Medicine.)

J.D. HARE, Starting from scratch, published by the author (PO Box 3044, Butztown, PA 18017, USA), 1983, $\$ 3.00$.

RICHARD F. MOULD, Mould's medical anecdotes, Bristol, Adam Hilger, 1984, 8vo, pp. xii, 147 , illus., $£ 9.95$.

AXEL HINRICH MURKEN, Lehrbuch der medizinischen Terminologie, Stuttgart, Kohlhammer, 1985, 8vo, pp. 237, DM.36.00.

DEREK J. ODDY and DEREK S. MILLER (editors), Diet and health in modern Britain, London, Croom Helm, 1985, 8vo, pp. 325, £22.50.

HANS PFEIL and HEINRICH SCHIPPERGES, Der menschliche Leib aus medizinscher und philosophischer Sicht, Aschaffenbert, Paul Pattloch Verlag, 1984, 8vo, pp. 142, DM.18.50 (paperback).

JANICE REID (editor), Body, land and spirit. Health and healing in aboriginal society, St Lucia, London. and New York, University of Queensland Press, 1982, 8vo, pp. xvi, 241,. $\$ 32.50$.

ULRICH ROSENBERG, Szenarium einer Revolution, Berlin DDR, Akademie Verlag, 1984, 8vo, pp. 266, M.28.00 (paperback).

IVOR WATERS, The parish doctor, Chepstow, Moss Rose Press (41 Hardwick Avenue, Chepstow, Gwent NP6 5DS), 8vo, pp. 20, 11.50 (paperback). 